\title{
Role of Peripheral Blood Mononuclear Cells in the Predisposition of Obese Individuals to Inflammation and Infection
}

\author{
Dror Dicker $^{a} \quad$ Mahmud Abo Salook $^{a} \quad$ Dana Marcoviciu $^{a} \quad$ Meir Djaldetti ${ }^{b}$ \\ Hanna Bessler ${ }^{b}$ \\ ${ }^{a}$ Department of Medicine D, b Laboratory for Hematology and Immunology Research, \\ Rabin Medical Center-Hasharon Hospital, Petah-Tiqva, and the Sackler School of Medicine, \\ Tel-Aviv University, Ramat-Aviv, Israel
}

\section{Key Words}

Obesity · Peripheral blood mononuclear cells · Cytokines · Inflammation · Infection

\begin{abstract}
Objective: To compare the production of pro- and anti-inflammatory cytokines by peripheral blood mononuclear cells (PBMC) from obese but otherwise healthy individuals to that of normal-weight volunteers. Methods: 25 healthy normal-weight subjects and 41 obese individuals were enrolled. Weight and height were measured twice. PBMC were examined for their capacity to generate pro-inflammatory (TNF- $\alpha$, IFN- $\gamma$, IL-1 $\beta$, IL- 6, IL-2) and anti-inflammatory IL-10 and IL-1ra) cytokines. Results: PBMC from obese individuals, compared to those from subjects with normal weight showed an increased production of the pro-inflammatory cytokines IL-2 (6.7 \pm 0.4 . vs. $4.9 \pm 0.3 \mathrm{ng} / \mathrm{ml} ; \mathrm{p}=0.003)$, TNF- $\alpha(505 \pm 45 \mathrm{vs.} 277 \pm 32 \mathrm{pg} / \mathrm{ml} ; \mathrm{p}=$ $0.001)$, and IFN- $\gamma(93.8 \pm 6.0$ vs. $73.9 \pm 2.7 \mathrm{ng} / \mathrm{ml} ; \mathrm{p}=0.0016)$. However, PBMC from obese individuals produced a lower amount of the anti-inflammatory cytokine IL-10 (651 $\pm 72 \mathrm{pg} / \mathrm{ml})$ versus those from subjects with normal weight $(951 \pm 133 \mathrm{pg} / \mathrm{ml} ; \mathrm{p}=0.039)$. Conclusions: The findings imply that obese individuals are in a 'low-grade inflammatory state', presumed to be connected with metabolic and cardiovascular co morbidities. The surplus of pro-inflammatory cytokines produced by circulating mononuclear cells of obese individuals, together with those secreted by adipocytes and non-fat cells in the adipose tissue, may contribute to the predisposition of obese patients to inflammation and infections.
\end{abstract}


Dicker et al.: Role of Peripheral Blood Mononuclear Cells in the Predisposition of Obese Individuals to Inflammation and Infection

\section{Introduction}

Since the enduring spread of obesity and its co-morbidities is increasing at an alarming rate, its impact on human health presents a serious concern to health care providers [1]. The prevalence of obesity in adults of both genders in the USA in 2004 was $32.2 \%$ [2]. A crosssectional survey carried out in Israel during 1999-2000 showed a similar incidence of $22.9 \%$ (19.9\% for men and $25.8 \%$ for women, aged 25-64 years) [3]. The major complications of obesity include cardiovascular diseases and development of metabolic syndrome, including type 2 diabetes, malignancy, obstructive sleep apnea, and others [1, 4]. In addition, clinicians have paid attention to the increased susceptibility of obese individuals to infections compared to their normal-weight counterparts [5-8]. A similar trend has been observed in obese mice [9]. However, while the typical co-morbidities have drawn widespread attention, the increased risk of infections, as an obesity-associated complication, is still not completely elaborated. Karisson and Beck [5] have pointed out that obesity may affect negatively the immune system resulting in altered immune responses and susceptibility to infections. According to Bastard et al. [10] the innate immune system of obese subjects is persistently activated, a process that triggers generation of pro-inflammatory factors resulting in a low-grade inflammation of the white adipose tissue. Based on their T-cell source, cytokines are characterized as Th1 and Th2 types. Th1 cells produce IL-2, IFN- $\gamma$ and IL-12 capable to promote cellular immunity. Th2 cells are the source of IL-4 and IL-10, known to suppress cellular and to endorse humoral immunity. The pro-inflammatory cytokines, i.e. TNF- $\alpha$, IL-1 $\beta$, IL- 6 and the anti-inflammatory cytokine IL-1 receptor antagonist (IL-1ra), are produced mainly by macrophages. The linkage between obesity and chronic low-grade inflammation has been supported by others $[11,12]$. Lumeng and Saltiel [12] have thoroughly reviewed the factors promoting obesity-induced inflammation, such as altered immune responses, leukocyte activation, and increase in acute phase proteins. In this review and in other studies, macrophages infiltrating the fatty tissues and producing pro-inflammatory molecules have been shown to be an important issue in the etiology of chronic inflammation observed in obese individuals [13-15]. While these studies focus on the function of adipocytes and tissue macrophages, the aim of the present study was to assess the role of peripheral blood mononuclear cells (PBMC) from obese but otherwise healthy individuals in production of pro- and anti-inflammatory cytokines and to compare it to that of normal-weight healthy volunteers.

\section{Subjects and Methods}

The Rabin Medical Center-Human Studies Committee approved the study. 25 healthy normal-weight adult subjects, ( 21 females, and 4 males) and 41 obese individuals ( 32 females, 9 males) were included in the study. The participants from both groups were in a good general condition, they denied any complaints, and their family history was not contributory. Except for their everyday activities, the participants were not engaged in any additional physical exercises. Weight and height were measured twice without shoes and in light clothing. In the presence of a difference of $0.5 \mathrm{~cm}$ and $0.5 \mathrm{~kg}$ in height and weight, respectively, a third measurement was carried out. Table 1 shows that there was no noticeable difference in age, height, and blood pressure between individuals from both groups. On the other hand, their body weight, BMI value, and waist circumference differed significantly. The relevant serum biochemistry examinations are presented in table 2 . Two obese individuals showed elevated fasting blood glucose (132 and $140 \mathrm{mg} / \mathrm{dl}$ ) without any complaints suggestive for diabetes.

\section{Cell Preparation and Culture Conditions}

PBMC were isolated from heparinized venous blood using lymphoprep gradient centrifugation. The cells were washed twice in phosphate buffered saline (PBS) and suspended in new-born calf serum (Biological Industries, Beith Haemek, Israel) supplemented with $10 \%$ dimethyl sulphoxide (DMSO) Sigma- 
Dicker et al.: Role of Peripheral Blood Mononuclear Cells in the Predisposition of Obese Individuals to Inflammation and Infection

Table 1. Demographic data of individuals from the two groups

\begin{tabular}{|c|c|c|c|c|c|}
\hline \multirow{3}{*}{$\mathrm{F} / \mathrm{M}$ ratio } & \multicolumn{2}{|c|}{ Non obese $(n=25)$} & \multicolumn{2}{|c|}{ Obese $(n=41)$} & \multirow[t]{2}{*}{$\mathrm{p}$ value } \\
\hline & $21 / 4$ & & $32 / 9$ & & \\
\hline & range & mean \pm SD & range & mean \pm SD & \\
\hline Age, years & $20-53$ & $33.1 \pm 9.7$ & $28-54$ & $40.4 \pm 7.1$ & 0.001 \\
\hline Body weight, kg & $45-78$ & $55.1 \pm 9.8$ & $69-125$ & $93.7 \pm 12.8$ & $<0.0001$ \\
\hline Height, m & $1.5-1.76$ & $1.64 \pm 0.07$ & $1.5-1.84$ & $1.63 \pm 0.07$ & NS \\
\hline BMI & $17.8-25$ & $20.95 \pm 2.4$ & $30.1-48.28$ & $35.2 \pm 4.0$ & $<0.0001$ \\
\hline Waist circumference, $\mathrm{cm}$ & $63-92$ & $74.8 \pm 8.9$ & $86-124$ & $108.4 \pm 9.0$ & $<0.0001$ \\
\hline SBP, mm Hg & $93-152$ & $113 \pm 12.4$ & $102-149$ & $126.5 \pm 11.3$ & $<0.0001$ \\
\hline $\mathrm{DBP}, \mathrm{mm} \mathrm{Hg}$ & $53-95$ & $69.7 \pm 9.7$ & $63-92$ & $79.4 \pm 8.0$ & $<0.001$ \\
\hline
\end{tabular}

SBP = Systolic blood pressure; DPP = diastolic blood pressure; NS = not significant.

Table 2. Serum biochemistry of individuals from the two groups

\begin{tabular}{|c|c|c|c|c|c|}
\hline & \multicolumn{2}{|c|}{ Non obese $(n=25)$} & \multicolumn{2}{|c|}{ Obese $(n=41)$} & \multirow[t]{2}{*}{$\mathrm{p}$ value } \\
\hline & range & mean \pm SD & range & mean \pm SD & \\
\hline Glucose, mg/dl & $72-112$ & $90.1 \pm 8.3$ & $69-140$ & $92.4 \pm 17.2$ & NS \\
\hline Cholesterol, mg/dl & $154-252$ & $190.3 \pm 30.7$ & $127-289$ & $189.7 \pm 31.4$ & NS \\
\hline Triglycerides, mg/dl & $41-430$ & $91.2 \pm 75.7$ & $52.3 \pm 460$ & $142.0 \pm 77.8$ & 0.0128 \\
\hline HDL, mg/dl & $32.2-94.3$ & $63.6 \pm 13.9$ & $28.1-66.8$ & $44.1 \pm 9.3$ & $<0.0001$ \\
\hline LDL, mg/dl & $63-174$ & $108.5 \pm 29$ & $66-149$ & $117.3 \pm 22.6$ & NS \\
\hline
\end{tabular}

NS = Not significant

Aldrich, Rehovot, Israel). Cell suspensions were freezed at $-75^{\circ} \mathrm{C}$ until assayed for cytokine secretion. On the day of assay, the cells were rapidly thawed and suspended in RPMI-1640 medium containing 1\% penicillin, streptomycin and nystatin, and supplemented with $10 \%$ fetal calf serum, designated as complete medium (CM).

\section{Cytokine Production}

$2 \times 10^{6}$ PBMC suspended in $1 \mathrm{ml} \mathrm{CM}$ were incubated for $24 \mathrm{~h}$ with $20 \mathrm{ng} / \mathrm{ml}$ lipopolysaccharide (LPS, $E$. coli, Sigma) to determine the secretion of TNF- $\alpha$, IL-1 $\beta$, IL-6, IL-1ra and IL-10. To evaluate IL-2 and IFN- $\gamma$ production the cells were incubated for $48 \mathrm{~h}$ with $1 \mu \mathrm{g} / \mathrm{ml}$ of phorbol meristate acetate (PMA) and $0.5 \mu \mathrm{g} / \mathrm{ml}$ of ionomycin (both from Sigma-Aldrich). The plates were incubated at $37^{\circ} \mathrm{C}$ in a humidified atmosphere containing $5 \% \mathrm{CO}_{2}$. At the end of the incubation period, the culture media were collected, the cells were removed by centrifugation, and the supernatants were kept at $-75^{\circ} \mathrm{C}$ until assayed for cytokine content.

\section{Cytokine Content in the Supernatants}

The concentration of cytokines in the supernatants was tested using ELISA kits specific for human cytokines (Biosource International, Camarillo, CA, USA) as detailed in the guideline provided by the manufacturer. The detection level of all cytokines was $30 \mathrm{pg} / \mathrm{ml}$.

\section{Statistical Analysis}

Data was analyzed using two tailed, independent Student's t-test. The results are expressed as mean \pm SEM. A p value $<0.05$ was considered as statistically significant. 
Dicker et al.: Role of Peripheral Blood Mononuclear Cells in the Predisposition of Obese Individuals to Inflammation and Infection

Table 3. Cytokine production by PBMC from non-obese and obese individuals

\begin{tabular}{|c|c|c|c|}
\hline Cytokines & Non-obese $(n=25)$ & Obese $(n=41)$ & $\mathrm{p}$ value \\
\hline \multicolumn{4}{|l|}{ Pro-inflammatory } \\
\hline TNF- $\alpha, p g / m l$ & $277 \pm 31$ & $505 \pm 45$ & 0.0006 \\
\hline IFN- $\gamma, \mathrm{ng} / \mathrm{ml}$ & $74.0 \pm 2.65$ & $93.1 \pm 6.0$ & 0.019 \\
\hline $\mathrm{IL}-1 \beta, \mathrm{ng} / \mathrm{ml}$ & $3.94 \pm 0.34$ & $3.78 \pm 0.28$ & 0.7299 \\
\hline IL-6, ng/ml & $15.63 \pm 2.32$ & $13.53 \pm 1.13$ & 0.3648 \\
\hline IL-2, ng/ml & $4.92 \pm 0.34$ & $6.66 \pm 0.38$ & 0.0029 \\
\hline \multicolumn{4}{|l|}{ Anti-inflammatory } \\
\hline IL-10, pg/ml & $952 \pm 127$ & $651 \pm 73$ & 0.04 \\
\hline IL-1ra, pg/ml & $930 \pm 99$ & $895 \pm 52$ & 0.264 \\
\hline
\end{tabular}

\section{Results}

\section{Pro-Inflammatory Cytokines (Table 3)}

The secretion of TNF- $\alpha$ by PBMC of the obese patients was significantly higher than that of the controls ( $505 \pm 45 \mathrm{pg} / \mathrm{ml}$ vs. $277 \pm 31 \mathrm{pg} / \mathrm{ml} ; \mathrm{p}=0.0006)$. Similarly, IFN- $\gamma$ production by PBMC of obese patients was significantly higher than that produced by cells of control individuals $(93.1 \pm 6.0$ vs. $74.0 \pm 2.65 \mathrm{ng} / \mathrm{ml} ; \mathrm{p}=0.019)$.

The secretion of IL-1 $\beta$ and that of IL- 6 by PBMC of the obese individuals did not differ significantly from that of healthy subjects $(3.67 \pm 0.29$ vs. $3.94 \pm 0.32 \mathrm{ng} / \mathrm{ml}$ for IL-1 $\beta ; \mathrm{p}=$ 0.7299 , and $13.53 \pm 1.13$ vs. $15.63 \pm 2.32 \mathrm{ng} / \mathrm{ml}$ for IL-6; $\mathrm{p}=0.3648$ ).

The production of IL-2 by PBMC from obese individuals was significantly higher than that of cells from the control group ( $6.66 \pm 0.38$ vs. $4.92 \pm 0.34 \mathrm{ng} / \mathrm{ml} ; \mathrm{p}=0.0029)$

\section{Anti-Inflammatory Cytokines (Table 3)}

The capacity of PBMC from obese subjects to produce IL-10 was significantly lower than that of cells from normal-weight individuals ( $651 \pm 73$ vs. $952 \pm 127 \mathrm{pg} / \mathrm{ml} ; \mathrm{p}=0.04$ ). As for IL-1ra secretion by cells of obese subjects, it did not differ significantly from that of the controls ( $895 \pm 52$ vs. $930 \pm 99 \mathrm{pg} / \mathrm{ml} ; \mathrm{p}=0.264)$.

\section{Discussion}

The results of the present study demonstrate that PBMC from obese individuals, compared to those from subjects with normal weight, show an increased secretion of the pro-inflammatory cytokines TNF- $\alpha$, IFN- $\gamma$ and IL- 2 as well as a lower production of the anti-inflammatory cytokine IL-10. These findings suggest that obese individuals are in a state of a concealed inflammation, designated as 'low-grade inflammatory state', a condition presumed to be connected with the metabolic and cardiovascular co-morbidities of obesity [11-15]. Moreover, this inflammatory process may predispose obese individuals to infections that might be promptly activated by triggers that would not affect the immune system of nonobese subjects. It is notable, that the secretion of the pro-inflammatory cytokines IL- $1 \beta$ and IL-6 and that of the anti-inflammatory cytokine IL-1ra by PBMC of the two groups did not differ significantly. It is conceivable that in the absence of a potent trigger, the PBMC from obese individuals will not produce the all array of pro- and anti-inflammatory cytokines. The factors accountable for the predisposition of obese individuals to infections are not understood completely. It has been reported that obese individuals, compared with normal-weight controls, have decreased NK and CD8+ cells, as well as altered CD4+ cell numbers with a 
consequent increase in pro-inflammatory cytokine production [5]. In the present study, the Th1/Th2 balance in the group of obese individuals shifted from Th2 dominance towards a Th1 profile as indicated by a decrease in IL-10 production and an increased IL- 2 and IFN- $\gamma$ secretion. It is noteworthy that the white adipose tissue itself may produce both pro- and antiinflammatory cytokines with a consequent modification of the immune functions in obese patients [16]. A distinctive role in maintaining chronic inflammation in obese persons has been attributed to macrophages infiltrating the white adipose tissue [10,14-17]. Moreover, studies have shown the existence of a correlation between an increased number of adiposeinfiltrating macrophages and obesity. On the other hand, weight reduction has brought to a diminution of macrophage infiltration and improved immune competence [10,18]. Studies in mice suggest that adipose-tissue macrophages originate in the bone marrow [17]. Cancello and Clement [16] have reviewed in details the mechanisms by which these macrophages infiltrate adipose tissue and the way by which they contribute to the process of 'low-grade inflammation'. According to the authors, this process depends on paracrine, autocrine, and endocrine signals as well as on various cytokines, including leptin. In our study, the altered cytokine production detected in obese individuals, expressed by an increase of pro-inflammatory cytokines and a decrease of the anti-inflammatory IL-10, was observed while using PBMC. There are two ways to explain this observation - either the immune cells have been activated in the circulating blood by inflammatory molecules and metabolites in the vessels of obese individuals as it has been previously suggested [16], or their activation occurs in the adipose tissue resulting in an altered immune surveillance. It has been shown that the adipose tissue itself is a potent source of a considerable number of pro-inflammatory cytokines, such as TNF- $\alpha$, IL-6, IL-8, IL-10, IL-17, contributing to the development of insulin resistance as well as to morbidity and mortality in obese patients [19-23]. Moreover, pro-inflammatory cytokines have been detected not only in the circulating blood but also in the follicular fluid of infertile obese women [24]. It is noteworthy that, although the adipose tissue itself is a resource for a large number of cytokines, many of them, excluding leptin and adiponectin, are produced by non-fat cells infiltrating the adipose tissue [25, 26].

In short, the present study demonstrates that PBMC from obese individuals produce more pro-inflammatory and less anti-inflammatory cytokines than those of normal-weight subjects. It is suggested that the alteration of the immune response of PBMC from obese persons is acquired either during the process of infiltration and stopover of the cells in the fat tissue or by products released from the adipose tissue into the circulation. The excess of proinflammatory cytokines produced by adipocytes and non-fat cells in the fatty tissue and those produced by circulating mononuclear cells may contribute to the predisposition of obese patients to inflammation and infections.

\section{Disclosure Statement}

There was no grant support for this work and there are not conflicts of interest.

\section{References}

1 Gnacinska M, Malgorzewicz S, Stojek M, Lysiak-Szydlowska W, Sworczak K: Role of adipokines in complications related to obesity: a review. Adv Med Sci 2009;54:150-157.

2 Pi-Suner X: The medical risks of obesity. Postgrad Med 2009;121:21-33.

-3 Keinan-Boker K, Noyman N, Ccinich A, Green MS, Nitzan-Kaluski D: Overweight and obesity in Israel: findings of the first health and nutrition survey (MABAT). Isr Med Assoc J 2005; 7:219-223.

4 Azagury DE, Lautz DB: Obesity overview: epidemiology, health and financial impact, and guidelines for qualification for surgical therapy. Gastrointest Endosc Clin N Am 2011;21:189-201. 
Dicker et al.: Role of Peripheral Blood Mononuclear Cells in the Predisposition of Obese Individuals to Inflammation and Infection

5 Karisson EA, Beck MA: The burden of obesity on infectious disease. Exp Biol Med 2010;235:1412-1424

6 Wick EC, Hirose K, Shore AD, Clark JM, Gearhart SL, Efron J, Makary MA: Surgical site infections and cost in obese patients undergoing colorectal surgery. Arch Surg 2011;146:1068-1072.

-7 Viasus D, Pano-Pardo JR, Pachon J, Campins A, Lopez-Medrano F, Villosiada A, Farinas MC, Moreno A, RodriguezBano J, Oteo JA, Martinez-Montauti J, Torre-Cisneros J, Segura F, Gudiol F, Carratala J, Novel Influenza A (H1N1) Study Group of the Spanish Network for Research in Infectious Diseases (REIP): Factors associated with severe disease in hospitalized adults with pandemic (H1N1) 2009 in Spain. Clin Microbiol Infect 2011;17: 738-746

-8 Tominaga M, Uno K, Yagi K, Fukui M, Hasegawa G, Yoshikawa T, Nakamura N: Association between capacity of interferon-alpha production and metabolic parameters. J Interferon Cytokine Res 2010;30:451-454.

-9 Easterbrook JD, Dunfee RL, Schwartzman LM, Jagger BW, Sandouk A, Kash JC, Memolo MJ, Taubenberger JK: Obese mice have increased morbidity and mortality compared to non-obese mice during infection with the 2009 pandemic H1N1 influenza virus. Influenza Other Respi Viruses 2011;5:418-425.

$>10$ Bastard JP, Maachi M, Lagathu C, Kim MJ, Caron M, Vidal H, Capeau J, Feve B: Recent advances in the relationship between obesity, inflammation, and insulin resistance. Eur Cytokine Netw 2006;17:4-12.

11 Hotamisligil GS: Inflammation and metabolic disorders. Nature 2006;444:860-867.

12 Lumeng CN, Saltiel AR. Inflammatory links between obesity and metabolic disease. J Clin Invest 2011;121: 2111-2117.

-13 Wellen KE, Hotamisligil GS: Obesity-induced inflammatory changes in adipose tissue. J Clin Invest 2003;112: 1785-1788.

14 Ramalho R, Guimaraes C: The role of adipose tissue and macrophages in chronic inflammation associated with obesity: clinical implications. Acta Med Port 2008;21:489-496.

15 Subramanian V, Ferrante AW Jr: Obesity, inflammation and macrophages. Nestle Nutr Workshop Ser Pediatr Program 2009;63:159-162.

16 Cancello R, Clement K: Is obesity an inflammatory illness? Role of low grade inflammation and macrophage infiltration in human white adipose tissue. BJOG 2006;113:1141-1147.

$\checkmark 17$ Weisberg SP, McCann D, Desai M, Rosenbaum M, Leibel RL, Ferrante AW Jr: Obesity is associated with macrophage accumulation in adipose tissue. J Clin Invest 2003;112:1796-1808.

18 Lamas O, Marti A, Martinez JA: Obesity and immunocompetence. Eur J Clin Nutr 2002;56(Suppl 3):542-545

19 Ahmed M, Gaffen SL: IL-17 in obesity and adipogenesis. Cytokine Growth Factor Rev 2010;449-453.

20 Grimble RF: The true cost of in-patient obesity: impact of obesity on inflammatory stress and morbidity. Proc Nutr Soc 2010;69:511-517.

21 Fantuzzi G: Adipose tissue, adipokines, and inflammation. J Allergy Clin Immunol 2005;115:911-919.

-22 Tam CS, Gamett SP, Cowell CT, Heilbron LK, Lee JW, Wong M, Baur LA: IL-6, IL-8 and IL-10 levels in healthy weight and overweight children. Horm Res Paediatr 2010;73:128-134.

23 Tzanavari T, Giannogonas P, Karalis KP: TNF-alpha and obesity. Curr Dir Autoiummun 2010;11:145-156

24 La Vignera S, Condorelli R, Bellanca S, La Rosa B, Mousavi A, Busa B, Vicari LO, Vicari E: Obesity is associated with a higher level of pro-inflammatory cytokines in follicular fluid of women undergoing medically assisted procreation (PMA) programs. Eur Rev Med Pharmacol Sci 2011;15:267-273.

-25 Fain JN: Release of interleukins and other inflammatory cytokines by human adipose tissue is enhanced in obesity and primarily due to nonfat cells. Vitam Horm 2008;74:443-477.

26 Fain JN, Bahouth SW, Madan AK: TNF $\alpha$ release by nonfat cells of human adipose tissue. Intern J Obes 2004;28: 616-622. 